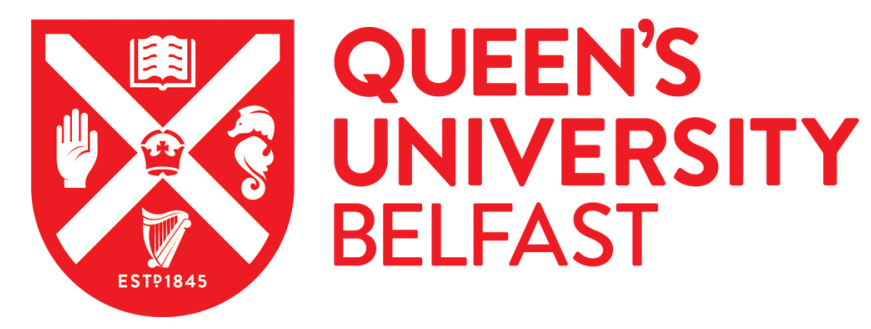

\title{
Warming affects predatory faunal impacts upon microbial carbon cycling
}

Hunter, W. R., Ogle, N., \& O'Connor, N. (2019). Warming affects predatory faunal impacts upon microbial carbon cycling. Functional Ecology. https://doi.org/10.1111/1365-2435.13304

\author{
Published in: \\ Functional Ecology
}

Document Version:

Peer reviewed version

Queen's University Belfast - Research Portal:

Link to publication record in Queen's University Belfast Research Portal

Publisher rights

(C) 2019 British Ecological Society.

This work is made available online in accordance with the publisher's policies. Please refer to any applicable terms of use of the publisher.

\section{General rights}

Copyright for the publications made accessible via the Queen's University Belfast Research Portal is retained by the author(s) and / or other copyright owners and it is a condition of accessing these publications that users recognise and abide by the legal requirements associated with these rights.

Take down policy

The Research Portal is Queen's institutional repository that provides access to Queen's research output. Every effort has been made to ensure that content in the Research Portal does not infringe any person's rights, or applicable UK laws. If you discover content in the Research Portal that you believe breaches copyright or violates any law, please contact openaccess@qub.ac.uk. 


\title{
Functional Ecology
}

DR WILLIAM ROSS HUNTER (Orcid ID : 0000-0001-8801-7947)

Article type : Research Article

Section: Ecosystems Ecology

Editor: Dr Rana El-Sabaawi

\section{Warming affects predatory faunal impacts upon microbial carbon cycling}

\author{
William Ross Hunter ${ }^{1,2 *}$, Neil Ogle3; Nessa O'Connor ${ }^{2,4}$. \\ ${ }^{1}$ School of Geography and Environmental Science, Ulster University, Coleraine, BT52 \\ 1SA, Northern Ireland (Present Address). \\ ${ }^{2}$ Queen's University Marine Laboratory, School of Biological Sciences, Queen's University \\ of Belfast, Portaferry, BT22 1PF, Northern Ireland. \\ ${ }^{3}$ Queen's University Stable Isotope Facility, School of Natural and Built Environment, \\ Queen's University of Belfast, Belfast, BT7 1NN, Northern Ireland. \\ ${ }^{4}$ School of Natural Sciences, Trinity College Dublin, Dublin 2, Ireland (Present Address).
}

*Corresponding author: Email: w.hunter@ulster.ac.uk

\begin{abstract}
1. Ocean warming and the loss of larger (often predatory) fauna are major threats to seabed (benthic) ecosystem functioning. Yet we know little about the combined effects of warming and faunal species loss upon the marine carbon cycle.
\end{abstract}

This article has been accepted for publication and undergone full peer review but has not been through the copyediting, typesetting, pagination and proofreading process, which may lead to differences between this version and the Version of Record. Please cite this article as doi: 10.1111/1365-2435.13304

This article is protected by copyright. All rights reserved. 
2. Using stable-isotope pulse-chase experiments, we tested how faunal species loss affects microbial carbon sequestration and retention in intertidal sediments, under both ambient and predicted future warming conditions (ambient $+2^{\circ} \mathrm{C}$ ), using the shore crab Carcinus maenas as a model predator. We traced the fixation and retention of a fixed dose of ${ }^{13} \mathrm{C}$-labelled sodium bicarbonate within sediment organic matter and microbial biomass.

3. Carcinus presence was associated with higher total organic carbon concentration within the mesocosm sediments. Temperature had no significant effect upon sediment total organic carbon concentrations. Temperature and Carcinus presence had no significant effect on polar lipid fatty acids (PLFAs) concentrations within the sediment, which is a proxy for microbial biomass.

4. Carcinus presence increased retention of ${ }^{13} \mathrm{C}$-labelled carbon within the sediment organic matter pool under future warming conditions. Retention of the ${ }^{13} \mathrm{C}$-label within the microbial PLFAs decreased significantly under futurewarming conditions.

5. Changes in the relative abundance of PLFAs revealed increased contribution of microeukaryotes to the microbial community under ambient conditions, in the absence of Carcinus. PLFA profiles revealed significant changes in ${ }^{13} \mathrm{C}$-label retention within the bacteria and microeukaryotes, driven by interactions between Carcinus presence and temperature.

6. Given that temperature is a fundamental control on the metabolic activity of marine organisms (from bacteria to metazoans), we propose that interactions between faunal species loss and ocean warming will have a pronounced effect upon marine carbon budgets.

Key-words Blue Carbon; Carbon Cycle; Carcinus maenas; Faunal loss; Microphytobenthos; PLFA; Predator; Sediment; Stable isotope

\section{Introduction}

Present estimates indicate that global temperatures will rise by at least $2^{\circ} \mathrm{C}$ by the end of the twenty-first century (IPCC 2014). This will have pronounced impacts upon the species distributions, phenology and the metabolic activity of many organisms, in particular those in marine ecosystems (Pauly et al. 1998; Burrows et al. 2011; Bellard et al. 2012; Poloczanska et al. 2013a; Payne et al. 2016). Through its effects upon the metabolic demands of organisms, ocean warming will alter the strength of interactions between autotrophic (primary producer) and heterotrophic (consumer) organisms and affect the rates and pathways for carbon and nutrient cycling (Daufresne, Lengfellner \& Sommer 2009; López-Urrutia et al. 2009; O'Connor et al. 2009). Metabolic theory predicts that the influence of temperature upon organismal metabolism is negatively associated with body-size (Ernest et al. 2003). Consequently, microbial processes that dominate carbon and nutrient cycling in marine sediments are predicted to be particularly sensitive to ocean warming (Gillooly et al. 2001; Weston \& Joye 2005; Daufresne et al. 2009; Morán et al. 2015).

This article is protected by copyright. All rights reserved. 
Current rates of marine species loss are comparable with past mass extinctions, although the present situation is unique in disproportionately affecting larger organisms living at the seabed (Payne et al. 2016). These benthic fauna are functionally important as predators and ecosystem engineers (Jones, Lawton \& Shachak 1994; O'Connor et al. 2009; van Nugteren, Herman et al. 2009; Atwood et al. 2013; O'Connor et al. 2013). Faunal activity has cascading effects through benthic food-webs potentially affecting organic matter preservation (Spivak et al. 2007; Jeffreys, Rachel M., Wolff \& Murty 2009; Fanjul et al. 2015), microbial activity (e.g. van Nugteren, Herman et al. 2009; Hunter, Veuger \& Witte 2012; Hunter et al. 2013) the trophic transfer of carbon and other nutrients (e.g. O'Connor et al. 2009; O'Connor et al. 2013; O'Connor \& Donohue 2013; Atwood et al. 2013) and, the energetic demands of seafloor ecosystems (Piepenburg et al. 1995). Larger predatory fauna, such as crabs, typically exhibit patchy spatial distributions at the seafloor and are highly mobile (Jones, et al. 2014; Atwood et al. 2015; Yool et al. 2017). To counter this, experimental manipulations provide a robust methodology to test how the loss of consumers affects ecosystem functioning under different environmental contexts (Canuel et al. 2007; Spivak et al. 2007; O'Connor et al. 2013; O'Connor \& Donohue 2013).

Non-vegetated coastal sediments are important to the global carbon cycle, accounting for between 13 and $28 \%$ of total marine carbon burial ( 226 - $418 \mathrm{Tg} \mathrm{C}_{\mathrm{yr}}^{-1}$; Cai 2011; Bauer et al. 2013; Atwood et al. 2015). Over the past 50 years, their areal coverage has increased by between 25 and $50 \%$, driven by changes in land use, climate change and nutrient enrichment (Atwood et al. 2015). In coastal sediments, the microphytobenthos (MPB) are an assemblage of unicellular eukaryotic algae and cyanobacteria that grow in the upper millimetres of illuminated sediments (MacIntyre, Geider \& Miller 1996). As such, the MPB are the main primary producers in non-vegetated sediments, contributing up to $50 \%$ of the primary productivity in coastal ecosystems (Underwood \& Kronkamp 1999). The MPB play a critical role in carbon fixation and storage in the sediment organic matter pool (Middelburg et al. 2000; Evrard et al. 2010), provide a food source for benthic fauna (Miller, Geider \& MacIntyre 1996; Middelburg et al. 2000; Evrard et al. 2010) and, produce extracellular polysaccharides that contribute to sediment stabilisation (Miller et al. 1996; Tolhurst et al. 2006; Spears et al. 2008) and provide a labile organic matter source for heterotrophic microorganisms (Oakes \& Eyre 2014). As the area of non-vegetated coastal sediments continues to grow, their responses to the cumulative impacts of faunal species loss and ocean warming will have major implications for carbon cycling in the future ocean.

The impacts of environmental change upon ecosystem processes remains a ecological 'black box' (Burrows et al. 2011; Cardinale et al. 2012; Poloczanska et al. 2013b; Halpern et al. 2015). Stable-isotope labelling experiments provide a powerful tool to open the box, by empirically tracing carbon and energy flow through a biological systems (Middelburg et al. 2000; Boschker, Kromkamp \& Middelburg 2005; van Nugteren et al. 2009; Evrard et al. 2010; Hunter et al. 2012; Mayor, Thornton \& Zuur 2012; Hunter et al. 2013). By tracing the incorporation and transfer of a carbon source enriched in the rare stable isotope carbon-13 $\left.{ }^{13} \mathrm{C}\right)$, over a fixed time period, we can test how environmental changes affect various aspects of the carbon cycle, such as carbon fixation and retention (Middelburg et al. 2000; Evrard et al. 2010) or the pathways for organic matter degradation (van Nugteren et al. 2009; van Nugteren, Moodley et al. 2009; Hunter et al.

This article is protected by copyright. All rights reserved. 
2012; Mayor et al. 2012; Hunter et al. 2013). In this study, we test how the presence of a benthic predator affected carbon fixation and retention rates in coastal sediments and, whether these putative effects differ between present climatic conditions and predicted future warming (ambient $+2{ }^{\circ} \mathrm{C}$ ) conditions (IPCC 2014). We focus upon the impacts of the shore crab Carcinas maenas (Linnaeus, 1758), hereafter Carcinus, a globally distributed predator / scavenger, commonly found on both soft and hard substrata in coastal habitats (Crothers 1968). Carcinus is an active bioturbator that excavates soft sediments, transporting buried sediment back to the surface (Queiros et al. 2013). We predicted that the effects of Carcinus upon carbon fixation and retention within coastal sediments will be mediated by ocean warming. We hypothesised that under ambient conditions, physical disturbance of the sediment surface by Carcinus limit the carbon fixation by the microphytobenthos, reducing ${ }^{13} \mathrm{C}$-retention within the sediment organic matter pool. Based on previous studies (e.g. Canuel et al. 2007; Spivak et al. 2007; Fanjul et al. 2015) we hypothesised that Carcinus presence would promote the preservation of non-isotopically labelled organic matter within the sediment and limit the accumulation of heterotrophic microbial biomass. As ocean warming is predicted to increase both faunal and microbial metabolic demands, we hypothesised that under future warming conditions (ambient $+2^{\circ} \mathrm{C}$ ) the direct (and indirect) effects of Carcinus presence upon carbon fixation and retention within coastal sediments would be amplified.

\section{Materials and Methods}

\subsection{Experimental Design and Set-up}

Stable isotope $\left({ }^{13} \mathrm{C}\right)$ pulse-chase experiments were conducted during February and March 2015 using outdoor flow-through mesocosms at Queen's University Marine Laboratory (Portaferry, Northern Ireland [Mrowicki \& 0'Connor 2015]). We assembled 20 mesocosms containing intertidal sediment manipulating two factors: 1 . Presence of Carcinus (two levels, present [single crab] and absent); and 2. temperature (two levels, ambient and warming [ambient $\left.+2^{\circ} \mathrm{C}\right]$ ). Mesocosms were arranged across four outdoor water baths, supplied with a constant flow of sand-filtered water from the adjacent Strangford Lough [flow rate $=27.84( \pm 4.89) \mathrm{l}_{\mathrm{h}} \mathrm{h}^{-1}$ ] and enclosed with plastic mesh lids, with a mesh size of $5 \mathrm{~mm}$, to prevent the crabs from escaping. Elevated temperature treatments were maintained using aquarium heaters (Elite Submersible 300W, Hagen Inc., USA) to warm two of the water baths. Mesocosms received a daily water change, leaving the sediment for 4 hours to simulate low tide. Prior to the daily water change, temperature, salinity, dissolved oxygen and $\mathrm{pH}$ were recorded within each mesocosm using a YSI 6-series sonde and multi-meter [YSI Inc. Ohio, USA] (Supplementary Table 1).

Sediment and Carcinus were collected from mudflats at Strangford Lough (54 $25^{\prime} 44^{\prime \prime} \mathrm{N}$; $5^{\circ} 32^{\prime} 34^{\prime \prime} \mathrm{W}$ ) between the $2^{\text {nd }}-6^{\text {th }}$ February 2015 . Sediments (less than $10 \mathrm{~cm}$ depth) were collected, homogenised and packed to $10 \mathrm{~cm}$ depth, in twenty $45 \mathrm{~L}$ opaque polypropylene boxes "mesocosms" (with internal dimensions $55.5 \times 35.5 \times 22.0 \mathrm{~cm}$ ). Collected sediments were a fine muddy-sand composed of $4.40 \pm 1.69 \%$ coarse sand (> $1000 \mathrm{um}$ ), $69.22 \pm 3.20 \%$ fine sand ( $>63 \mathrm{um}$ ) and $26.37 \pm 2.69 \%$ silt ( $<63 \mathrm{um}$ ), with a sand: silt ratio of $2.85 \pm 0.25$. Sediment pore water content was $35.29 \pm 0.87 \%$ and porosity was calculated as $0.04 \pm 0.01$.

This article is protected by copyright. All rights reserved. 
Experiments were conducted over 4 weeks (28 days). A single male crab (carapace width $=3.47[ \pm 0.14] \mathrm{cm}$, wet biomass $=9.66[ \pm 2.21] \mathrm{g}$ ) placed into five ambient and five warmed mesocosms 7 days after the incubations commenced; a $24 \mathrm{mg}\left(0.1 \mathrm{~g} \cdot \mathrm{m}^{-2}\right)$ dose of ${ }^{13} \mathrm{C}$-labelled sodium bicarbonate was sprayed directly onto the sediment surface of all mesocosms on day 21. The experiments were then incubated for a further 5 days and then destructively sampled to quantify ${ }^{13} \mathrm{C}$-incorporation and retention in microbial biomass and the sediment organic matter pool, following Middelburg et al. (2000).

Changes in the biomass and spatial variability of the sediment microphytobenthos (MPB) were measured within each mesocosm using a BBE Moldänke BenthoTorch [BBE Moldänke Gmbh, Schwentinental, Germany] to quantify surficial chlorophyll a ( $\mathrm{Chl}_{\mathrm{a}}$ ) concentrations after 7 (Week 0), 14 (Week 1), 21 (Week 2) and 28 (Week 3) days (Kahlert \& McKie 2014). At each interval five replicate measurements of the surficial $\mathrm{Chl}_{\mathrm{a}}$ were made, within each mesocosm. Mean $\mathrm{Chl}_{\mathrm{a}}$ concentrations within each mesocosm were estimated as a proxy for MPB biomass, with the coefficient of variation of the $\mathrm{Chl}_{\mathrm{a}}$ measurements within each mesocosm providing a metric for MPB patchiness within each mesocosm.

After 28 days, the mesocosm sediments were randomly sampled using four $8 \mathrm{~cm}$ diameter push cores. These were horizontally sectioned into $0-0.5 ; 0.5-2 ; 2-5 ; 5-10 \mathrm{~cm}$ depth fractions. Depth fractions from each of the four cores were pooled, homogenised and lyophilised $\left(-68^{\circ} \mathrm{C} ; 0.0001 \mathrm{mbar}\right)$, then stored frozen $\left(-20^{\circ} \mathrm{C}\right)$ prior to further analysis (Hunter et al. 2012; Hunter et al. 2013). Total organic carbon (TOC) and the retention of the ${ }^{13} \mathrm{C}$-label into the sediment organic carbon pool were determined using a Thermo Flash1112 Elemental Analyser interfaced with a Delta V Isotope Ratio Mass Spectrometer [EA-IRMS]. Analytical precision, based on regular replicated analysis of two international standards (USGS 41 and CH7) was $< \pm 0.1 \%$ o. Prior to analysis, sediment samples were lyophilised, acid fumed with $6 \mathrm{~mol} \mathrm{l}^{-1}$ hydrochloric acid to remove inorganic carbon following Hedges and Stern (1984) and dried to constant weight at $60^{\circ} \mathrm{C}$.

Microbial biomass and retention of the ${ }^{13} \mathrm{C}$-label within the surficial $(0-0.5 \mathrm{~cm})$ sediments were quantified, using polar lipid fatty acids (PLFAs) as biomarkers. PLFAs were extracted from $3 \mathrm{~g}$ of lyophilized sediment using a modified Bligh-Dyer extraction protocol (White et al. 1979). Briefly, lipids were extracted over 2 hours using a singlephase extraction mixture of chloroform, methanol and citrate buffer $(1: 2: 0.8 \mathrm{v} / \mathrm{v} / \mathrm{v})$. Lipid extracts were fractionated on silicic acid columns (6 ml ISOLUTE SIS PE columns, International Sorbent Technologies Ltd, Ystrad Mynach, UK) via sequential elution with chloroform (neutral lipid fatty acids), acetone (glycolipid fatty acids) and methanol (PLFAs). PLFAs were transmethylated to fatty acid methyl esters for analysis. PLFA concentrations and ${ }^{13} \mathrm{C} /{ }^{12} \mathrm{C}$-ratios were determined on a Thermo GC Trace Ultra gas chromatograph combustion interfaced to a Thermo Delta V Advantage isotope ratio mass spectrometer via a Thermo GC Combustion III (following Thornton et al. 2011). The ${ }^{13} \mathrm{C}$-enrichment of the TOC and PLFAs were then determined from the ${ }^{12} \mathrm{C} /{ }^{13} \mathrm{C}$ ratios, following Hunter et al. (2013), correcting for background isotopic ratios of each material (Supplementary tables $2 \& 3$ ). All data were scaled to the areal cover (per mesocosm) by converting to values per $\mathrm{cm}^{-3}$ of wet sediment, pooling the data for from each sediment

This article is protected by copyright. All rights reserved. 
depth fraction $(0-0.5 ; 0.5-2 ; 2-5 ; 5-10 \mathrm{~cm})$ and normalised to total mesocosm area $(0.24$ $\left.\mathrm{m}^{2}\right)$.

\subsection{Data Analysis}

We tested for significant interactions and independent effects of Carcinus presence and temperature by analysis of variance, treating Carcinus presence (2 levels: presence, absence) and temperature (2 levels: ambient, ambient $+2{ }^{\circ} \mathrm{C}$ ) as fixed effects. We included water bath as a random error term within the ANOVA models to account for the potential effects of mesocosm location (Underwood, 1997; Crawley 2007). ANOVA model structure may, thus, be expressed as $y \sim C^{*} T+$ Error $(W B)$, where $C=$ Carcinus presence, $T=$ Temperature and $W B$ is the Water Bath. Data and residuals were visually explored to ensure they met assumptions of normality and homoscedacity (following Zuur, Ieno \& Elphick 2010). We tested for the effects of Carcinus presence and temperature upon MPB biomass (sediment chlorophyll $a$ concentrations) and the spatial variability of the MPB community independently during each four weeks of the experiment. The inclusion of week as a covariate would have required the extension of the ANOVA model to include a 3-way interaction term and a temporal autocorrelation structure. This was deemed inappropriate given the sample size within each our treatments $(n=5)$.

Using the ANOVA model described above, we tested for treatment effects upon sediment TOC and $\mathrm{TO}^{13} \mathrm{C}$ concentrations, total PLFA and ${ }^{13} \mathrm{C}$-labelled PLFA concentrations as proxies for microbial biomass and microbial carbon retention at the end of the experimental incubations, and the relative abundance bacterial and microeukaryote fatty acid biomarkers (Supplementary Table 4) within both the total and ${ }^{13} \mathrm{C}$-labelled PLFA pools. We tested for statistical significance at $p<0.05$, as a reasonable compromise between the risk of false rejection of the null hypothesis (Type I error) and failure to detect a significant effect (Type II error), given the limited replication $(n=5)$ within each treatment (Underwood, 1997). Where we detect a significant p-value, we calculated the effect size $\left(\eta^{2}\right)$ as the sum of squares for any significant effect(s) / total sum of squares for the ANOVA model, following Cohen (1988). Effect sizes are reported alongside the p-values for each ANOVA in tables 1,2 and 3. We consider a small effect size where $\eta^{2}<0.15$; with the associated p-values interpreted with caution (Cohen 1988). Data analysis were conducted in $R$, using the base and Sciplot packages (R Development Core Team 2009; Morales 2012).

\section{Results}

Differences in the concentration and spatial variability of chlorophyll $a$ within surficial sediments were tested independently during each of the four time points (weeks $0,1,2$, 3 and 4), with Carcinus introduced to the mesocosms during week 1. Carcinus presence resulted in a significant decrease in MPB biomass during weeks 1 and 2 of the experiment, with no effects detected during weeks 0 and 3 (Figure 1a; Table 1a). Our data suggests a significant interaction between Carcinus presence and temperature

This article is protected by copyright. All rights reserved. 
affected MPB patchiness during week 1 (Fig. 1b; Table 1b), albeit with a small effect size $\left(\eta^{2}=0.112\right.$, Table $\left.1 \mathrm{~b}\right)$. No significant effects of Carcinus presence and temperature upon MPB patchiness were detected during weeks 2 or 3 (Fig. 1b). We, thus, infer that Carcinus presence affected the growth of the MPB negatively during weeks 1 and 2 of the experiment. No significant effects of water bath, as a nesting factor, were detected upon either MPB biomass or patchiness.

We observed a significant effect of Carcinus presence upon sediment TOC concentrations (Fig. 2a; Table 2a), which decreased by $15 \%$ when crabs were absent. ${ }^{13} \mathrm{C}$-label retention within the sediment $\left(\mathrm{TO}^{13} \mathrm{C}\right)$ accounted for between 0.02 and $0.42 \%$ of the ${ }^{13} \mathrm{C}$-labelled bicarbonate dose added to each mesocosm (Fig. 2b; Table 2b). We identified a significant interaction between Carcinus presence and temperature on sediment $\mathrm{TO}^{13} \mathrm{C}$. Carcinus presence decreased sediment $\mathrm{TO}^{13} \mathrm{C}$ concentrations but only under ambient conditions. Under the future warming conditions, by contrast, $\mathrm{TO}^{13} \mathrm{C}$ concentration within the sediments was greater in the presence of Carcinus.

We used the concentrations of PLFAs in surficial sediments as a proxy for total microbial

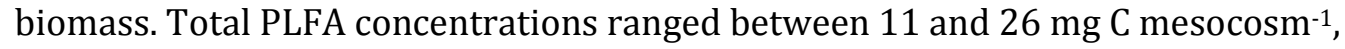
equating to between 15 and $36 \mathrm{~g}$ microbial biomass within each mesocosm (following Middelburg et al., 2000; Evrard et al., 2010). Within this study, we detected no effects of either Carcinus presence or temperature upon microbial biomass (Fig. 2c; Table 2c). Microbial ${ }^{13} \mathrm{C}$-retention was negatively affected by increased temperature (Fig. $2 \mathrm{~d}$; Table 2d).

In total, 31 individual PLFA were detected, of which five were identified as bacteriaspecific fatty acids and three polyunsaturated fatty acids (PUFAs) as microeukaryotespecific biomarkers (Supplementary Table 4). Bacterial contributions to the PLFAs exhibited a significant increase in response to warming, with no effects of Carcinus presence (Fig. 3a; Table 3a). Bacterial contributions to the ${ }^{13} \mathrm{C}$-labelled PLFAs were affected by significant interactions between Carcinus presence and temperature (Fig. 3b; Table 3b). Carcinus presence reduced ${ }^{13} \mathrm{C}$-labelling of the bacterial PLFAs under ambient conditions, and increased ${ }^{13} \mathrm{C}$-labelling of the bacterial PLFAs under the warming treatment.

Significant interactions between Carcinus presence and warming affected the relative abundance of both the microeukaryote PUFAs (Fig. 3c; Table 3c) and their contribution to the ${ }^{13} \mathrm{C}$-labelled PLFA pool (Fig. 3d; Table 3d) in both cases Carcinus presence and warming resulted in significant decreases in PUFA concentrations and 13C-labelling relative to the ambient-no crab treatment. The most commonly detected polyunsaturated PLFA was $18: 2 \omega 6,9$, which is widely recognised as a fungal biomarker (Stoeck et al. 2002; Kaiser et al. 2010; Frostegård, Tunlid \& Bååth 2011), accounting for between $39.45( \pm 1.81) \%$ and $46.02( \pm 2.69 \%)$ of the total PUFAs.

This article is protected by copyright. All rights reserved. 


\section{Discussion}

The study shows that the presence of the mobile epibenthic predator, Carcinus maenas, mediated the retention of newly fixed $\left({ }^{13} \mathrm{C}\right.$-labelled) carbon within intertidal sediments, with faunal impacts altered by changes to the ambient temperature. MPB biomass and patchiness, (proxies for assessing the productive potential of coastal sediments, Hicks et al. 2009; Kahlert \& McKie 2014), were both initially affected by the introduction of Carcinus to the mesocosms. Where Carcinus were present, the sediment surface was visibly disturbed with track marks, and appeared loss cohesive in texture. Alongside this disturbance the MPB biomass increased and MPB patchiness decreased over the subsequent two weeks, suggesting that faunal reworking of the sediment had little long term effects upon the MPB. This is surprising given that faunal disturbance tends to limit the accumulation of MPB biomass or fresh algal phytodetritus at the sediment surface (Canuel et al. 2007; Spivak et al. 2007; Hicks et al. 2009; Jeffreys et al. 2011; Fanjul et al. 2015). However, benthic diatoms can switch between autotrophy at the sediment surface and heterotrophic fermentation within oxygen and light limited sub-surface sediments (Bourke et al. 2016). We postulate that faunal reworking of the sediments provides a mechanism for the transfer of active MPB cells between the sediment surface and deeper sediment layers, which allows MPB biomass to recover from the initial disturbance event.

Coastal regions are important in the global carbon cycle, where organic matter burial exceeds $226 \mathrm{Tg} \mathrm{C} \mathrm{yr}^{-1}$, of which up to $50 \%$ may be recycled back to the water column as carbon dioxide (Middelburg, Soetaert \& Herman 1997; Bauer et al. 2013).

Understanding how fauna influence these processes is critical if we are to predict the impacts of the current high rates of biodiversity loss. Within our study, the bulk of the sediment TOC pool consisted of non-labelled organic matter and can, thus, be considered analogous with 'old' carbon stored within the sediment. Carcinus absence was associated with a small, but significant, decrease in the retention of this 'old' carbon within the sediment (Fig. 2a). As an active bioturbator, Carcinus plays a key role reworking coastal sediments (Queiros et al. 2013). Given that sediment and crabs were collected from the same field site, it is reasonable to infer that sediment carbon stocks are in equilibrium with the presence of Carcinus. Consequently, the decrease in TOC associated with the absence of Carcinus suggests that faunal disturbance may limit microbial activity within the mesocosm sediments. This provides further evidence that benthic fauna, such as crabs, play an important role regulating microbial activity and the preservation of organic matter within coastal sediments (Mermillod-Blondin \& Rosenberg 2006; Canuel et al. 2007; Spivak et al. 2007; Fanjul et al. 2015).

The ${ }^{13} \mathrm{C}$-labelled organic matter represents a sedimentary carbon pool that has been "recently-fixed" by the MPB. This 'recently-fixed' carbon pool is likely to be composed of relatively labile short-chain organic molecules (e.g. lipids, amino acids), which may be preferentially utilised as a carbon source by the sediment microbial community (e.g. van Nugteren et al. 2009; Miyatake et al. 2014). Our study identified contrasting effects of Carcinus presence upon the concentrations of this 'recently-fixed' carbon under both the present and future warming conditions (Fig. 2b). No significant differences in surficial MPB biomass were observed during the isotope-labelling phase of the experiment (Fig. 1a) and, under ambient conditions, Carcinus presence had no effect upon ${ }^{13} \mathrm{C}$-fixation

This article is protected by copyright. All rights reserved. 
into the organic matter pool (Fig. 2B) Consequently, crab activity had no effect upon Cfixation by the MPB contrasting with previous studies that have identified faunal disturbance of the sediment surface as an important control upon microbial carbon fixation (Mermillod-Blondin \& Rosenberg 2006). Under the predicted future-warming treatment, however, the absence of Carcinus is associated with reduced retention of ${ }^{13} \mathrm{C}$ labelled carbon in the sediment. This indicates that under the predicted warming conditions tested, increased metabolic activity by the sediment microbial community, leading to more rapid fixation of the ${ }^{13} \mathrm{C}$-label by the MPB and more rapid mineralisation of 'recently-fixed' carbon by heterotrophic microorganisms (Gillooly et al. 2001; Weston \& Joye 2005; Daufresne et al. 2009; Morán et al. 2015).

The microbial response to Carcinus presence and warming were tested in the surficial sediment layer $(0-0.5 \mathrm{~cm})$, using PLFAs as biomarkers. PLFAs provide a powerful tool in this context, allowing both microbial biomass and incorporation of the ${ }^{13} \mathrm{C}$-label to be quantified (Middelburg et al. 2000; Mayor et al. 2012; Hunter et al. 2013). Microbial biomass (estimated from PLFA concentrations) was unaffected by either Carcinus presence or temperature (Fig. 2c), however, we observed a significant decrease in ${ }^{13} \mathrm{C}$ label retention within the PLFAs (Fig 2d). This is likely to reflect increased metabolic activity within the microbial community as a response to ocean warming (Weston \& Joye 2005). Carcinus presence played no significant role in determining ${ }^{13} \mathrm{C}$-label retention within the PLFAs. We suggest that turnover of microbial biomass at the sediment surface (reviewed in Mermillod-Blondin \& Rosenberg 2006), combined with temperature-dependent increases in microbial metabolism (Weston \& Joye 2005; Arndt et al. 2013) may explain this observation.

Our results show that faunal species loss has pronounced effects upon microbial community responses to ocean warming. In this context, Carcinus presence had a significant influence upon both the structure of the microbial community and its active component, as revealed from the relative abundance of bacteria-specific FAs and PUFAs within the total PLFA and ${ }^{13} \mathrm{C}$-labelled PLFA profiles. PLFAs can provide useful information on microbial community structure in aquatic sediments (e.g. Stoeck et al. 2002; Boschker et al. 2005; Mayor et al. 2012), albeit with caveats regarding their limited taxonomic resolution (Frostegård et al. 2011). We observed broad trends in the response of the microbial community within our mesocosms. This is characterised by temperature-driven decreases in the bacterial FAs, which reflect the impacts of ocean warming on microbial cell-size (Morán et al. 2015). There was a strong negative effect of crab presence upon the PUFAs under ambient conditions. PUFAs can be considered both as a biomarker of microeukaryote biomass (Stoeck et al. 2002; Kaiser et al. 2010; Frostegård et al. 2011) and an indicator of the relative lability of the sediment organic matter pool (Canuel et al. 2007; Spivak et al. 2007). Within our study, PUFAs were dominated by a single fungal biomarker (18:2 $\omega 7)$ suggesting that, under ambient conditions, Carcinus may suppress the accumulation of fungal biomass within surficial sediments. By contrast, PUFA concentrations were lower under future warming conditions, perhaps as a consequence of increases in resource competition and biomass turnover within the microbial community (Daufresne et al. 2009; Sarmento et al. 2010).

This article is protected by copyright. All rights reserved. 
The active microbial community, as revealed by ${ }^{13} \mathrm{C}$-labelling of the PLFAs, were sensitive to changes in Carcinus presence under both ambient and future-warming conditions. Both bacterial and microeukaryote biomarkers exhibited similar responses, with Carcinus presence associated with decreased contribution to the active microbial community under ambient conditions, but increasing their contributions under warming conditions. Our study builds upon previous studies which demonstrate that crabs play a key role in coastal sediments, controlling accumulation of microbial biomass and the preservation of organic matter (Canuel et al. 2007; Spivak et al. 2007; Fanjul et al. 2015). This reinforces the concept of the benthic fauna as a 'gearbox' that regulates microbial activity in marine sediments (van Nugteren et al. 2009; Hunter et al. 2012) and support the observation that the responses of faunal communities to rising ocean temperature will have cascading effects upon benthic primary producers (O'Connor et al. 2009; Mrowicki \& O'Connor 2015).

Retention of the ${ }^{13} \mathrm{C}$-label within the mesocosm sediment was low compared with other studies that investigated label uptake by the MPB (e.g. Middelburg et al. 2000; Boschker et al. 2005; van Oevelen et al. 2006). This reflects the relatively low dose of ${ }^{13} \mathrm{C}$-labelled sodium bicarbonate introduced into each mesocosm, and potential losses associated with washout of unused ${ }^{13} \mathrm{C}$-labelled sodium bicarbonate; mineralisation of ${ }^{13} \mathrm{C}$-labelled organic matter and flux of dissolved organic carbon between the sediment and overlying water (e.g. Middelburg et al. 2000; Evrard et al. 2010). Given that coastal sediments are typically respiration-dominated systems (Woulds et al. 2009; Woulds et al. 2016), mineralisation of ${ }^{13} \mathrm{C}$-labelled organic matter is likely to represent a major un-quantified process within our study. Caution is therefore advised in comparing these data with other sediment carbon budgets, derived using similar methodologies (Middelburg et al. 2000; Evrard et al. 2010; Woulds et al. 2016). Our study builds upon observations of cascading effects of crab predation upon sediment organic matter composition in coastal sediments (Canuel et al. 2007; Spivak et al. 2007; Fanjul et al. 2015), and provides a direct test of how faunal species loss affects sediment carbon sequestration under both present climatic conditions and predicted future-warming conditions.

Our study demonstrates that both faunal presence and temperature are important regulators for organic matter retention within coastal sediments. Faunal presence was the primary driver of changes in 'old' organic carbon within the mesocosm, whilst strong interactions between faunal presence and temperature determine the fate of 'recently-fixed' organic matter. Bulk analysis of the TOC and total PLFAs was, however, limited in its scope to identify the interacting effects of Carcinus presence and temperature. Compound-specific analysis of the PLFA profiles, allowed us, to discern how faunal presence stimulated ${ }^{13} \mathrm{C}$-incorporation by heterotrophic microbes under the predicted-future warming treatment, and suppressed the accumulation of microeukaryote (fungal) biomass under ambient conditions. These effects are clearly driven by changes in faunal bioturbation and the rate-limiting effects of temperature upon microbial activity.

We acknowledge that the results of mesocosm experiments are largely illustrative, and cannot easily be scaled to natural systems (Oviatt 1994; Carpenter 1996; Queiros et al. 2015). If we are to mitigate the impacts of global biodiversity loss, however, manipulative experiments are an important tool to test potential impacts on ecosystem

This article is protected by copyright. All rights reserved. 
processes (Duffy 2009; Cardinale et al. 2012; Stewart et al. 2013; Donohue et al. 2017). Previous mesocosm studies highlight the importance of epibenthic predators, such as crabs, as mediators of organic matter preservation in coastal sediments (Canuel et al. 2007; Spivak et al. 2007; Atwood et al. 2015; Donohue et al. 2017; Fanjul et al. 2015). Here we demonstrate that under future warming conditions, epibenthic predator loss leads to an increase in the relative importance of microbial $\mathrm{C}$ cycling pathways in coastal sediments. Whilst we cannot easily predict ecosystem-scale responses, this may result in decreasing carbon storage within coastal sediments. Consequently the combined effects of predator loss and ocean warming are likely to have adverse effects upon a range of coastal ecosystem services that are relevant for climate regulation, waste processing, flood protection and support of fisheries (reviewed in Lopes \& Vidiera 2013; Isbell et al. 2017).

\section{Acknowledgements}

We thank Henk Van Rein, Brendan MacNamara, Lydia White and Camilla Bertolini for the their help with the experimental work. We also thank the editor and reviewers, for their constructive comments, which greatly improved this paper. We acknowledge Barry Thornton and Maureen Procee at the James Hutton Institute for their assistance with compound-specific stable isotope analysis. Crab symbols were created by Hea Poh Lin from the Noun Project (https://thenounproject.com) and are used under a Creative Commons Licence (CC-BY). This study was funded through a Leverhulme Trust Early Career Fellowship (ECF-2014-057) to WRH and a Royal Society Research Grant (RG120432) to NEO'C. The authors declare no conflicts of interest.

\section{Author Contributions}

Experiments were designed by WRH and NO'C, and conducted by WRH. Analytical work was carried out by WRH and NO. WRH, NO and NO'C all contributed to the writing of the manuscript.

\section{Data Accessibility}

Data are deposited in the Pangaea data repository and available under a CC-BY creative commons license: https://doi.pangaea.de/10.1594/ PANGAEA.892199 (Hunter et al., 2018).

This article is protected by copyright. All rights reserved. 


\section{References}

Arndt, S., Jørgensen, B.B., LaRowe, D.E., Middelburg, J.J., Pancost, R.D. \& Regnier, P. (2013) Quantifying the degradation of organic matter in marine sediments: A review and synthesis. Earth-Science Reviews, 123, 53-86.

Atwood, T.B., Hammill, E., Greig, H.S., Katina, P., Shurin, J.B., Srivastava, D.S. \& Richardson, J.S. (2013) Predator-induced reduction of freshwater carbon dioxide emissions. Nature Geoscience, 6, 191-194.

Atwood, T.B., Connolly, R.M., Ritchie, E.G., Lovelock, C.E., Heithaus, M.R., Hays, G.C., Fourqurean, J.W. \& Macreadie, P.I. (2015) Predators help protect carbon stocks in blue carbon ecosystems. Nature Climate Change, 5, 1038-1045.

Bauer, J.E., Cai, W.J., Raymond, P.A., Bianchi, T.S., Hopkinson, C.S. \& Regnier, P.A.G. (2013) The changing carbon cycle of the coastal ocean. Nature, 504, 61-70.

Bellard, C., Bertelsmeier, C., Leadley, P., Thuiller, W. \& Courchamp, F. (2012) Impacts of climate change on the future of biodiversity. Ecology Letters, 15, 365-377.

Boschker, H.T.S., Kromkamp, J.C. \& Middelburg, J.J. (2005) Biomarker and carbon isotopic constraints on bacterial and algal community structure and functioning in a turbid, tidal estuary. Limnology and Oceanography, 50, 70-80.

Bourke, M.F., Marriott, P.J., Glud, R.N., Hasler-Sheetal, H., Kamalanathan, M., Beardall, J., Greening, C. \& Cook, P.L.M. (2016) Metabolism in anoxic permeable sediments is dominated by eukaryotic dark fermentation. Nature Geoscience, 10, 3035 .

Burrows, M.T., Schoeman, D.S., Buckley, L.B., Moore, P., Poloczanska, E.S., Brander, K.M., Brown, C., Bruno, J.F., Duarte, C.M., Halpern, B.S., Holding, J., Kappel, C.V., Kiessling, W., O’Connor, M.I., Pandolfi, J.M., Parmesan, C., Schwing, F.B., Sydeman, W.J. \& Richardson, A.J. (2011) The pace of shifting climate in marine and terrestrial ecosystems. Science, 334, 652-655.

Cai, W.J. (2011) Estuarine and coastal ocean carbon paradox: CO2 sinks or sites of terrestrial carbon incineration? Annual Reviews of Marine Science, 3, 123-145.

Canuel, E.A., Spivak, A.C., Waterson, E.J. \& Duffy, J.E. (2007) Biodiversity and food web structure influence short-term accumulation of sediment organic matter in an experimental seagrass system. Limnology and Oceanography, 52, 590-602.

Cardinale, B.J., Duffy, J.E., Gonzalez, A., Hooper, D.U., Perrings, C., Venail, P., Narwani, A., Mace, G.M., Tilman, D., Wardle, D.A., Kinzig, A.P., Daily, G.C., Loreau, M., Grace, J.B., Larigauderie, A., Srivastava, D.S. \& Naeem, S. (2012) Biodiversity loss and its impact on humanity. Nature, 486, 59-67.

Carpenter, S.R. (1996) Microcosm experiments have limited relevance for community and ecosystem ecology. Ecology, 77, 677-680.

This article is protected by copyright. All rights reserved. 
Cohen, J. (1988) The analysis of variance and covariance (chapter 8). Statistical Power Analysis for the Behavioral Sciences, pp. 273-406. Routledge, New York, USA.

Crawley, M.J. (2007) The R Book, 950 pp. John Wiley \& Sons Ltd, Chichester, UK.

Crothers, J.H. (1968) The biology of the shore crab Carcinus maenas (L.) 2. the life of the adult crab. Field Studies, 2, 579-614.

Daufresne, M., Lengfellner, K. \& Sommer, U. (2009) Global warming benefits the small in aquatic ecosystems. Proceedings of the National Academy of Sciences, 106, 12788-12793.

Donohue, I., Petchey, O.L., Kéfi, S., Génin, A., Jackson, A.L., Yang, Q. \& O'Connor, N.E. (2017) Loss of predator species, not intermediate consumers, triggers rapid and dramatic extinction cascades. Global Change Biology, 23, 2962-2972.

Duffy, J.E. (2009) Why biodiversity is important to the functioning of real-world ecosystems. Frontiers in Ecology and the Environment, 7, 437-444.

Ernest, S.K.M., Enquist, B.J., Brown, J.H., Charnov, E.L., Gillooly, J.F., Savage, V.M., White, E.P., Smith, F.A., Hadly, E.A., Haskell, J.P., Lyons, S.K., Maurer, B.A., Niklas, K.J. \& Tiffney, B. (2003) Thermodynamic and metabolic effects on the scaling of production and population energy use. Ecology Letters, 6, 990-995.

Evrard, V., Soetaert, K., Heip, C.H.R., Huettel, M., Xenopoulos, M.A. \& Middelburg, J.J. (2010) Carbon and nitrogen flows through the benthic food web of a photic subtidal sandy sediment. Marine Ecology Progress Series, 416, 1-16.

Fanjul, E., Escapa, M., Montemayor, D., Addino, M., Alvarez, M.F., Grela, M.A. \& Iribarne, O. (2015) Effect of crab bioturbation on organic matter processing in south west atlantic intertidal sediments. Journal of Sea Research, 95, 206-216.

Frostegård, A., Tunlid, A. \& Bååth, E. (2011) Use and misuse of PLFA measurements in soils. Soil Biology and Biochemistry, 43, 1621-1625.

Gillooly, J.F., Brown, J.H., West, G.B., Savage, V.M. \& Charnov, E.L. (2001) Effects of size and temperature on metabolic rate. Science, 293, 2248-2251.

Halpern, B.S., Frazier, M., Potapenko, J., Casey, K.S., Koenig, K., Longo, C., Lowndes, J.S., Rockwood, R.C., Selig, E.R., Selkoe, K.A. \& Walbridge, S. (2015) Spatial and temporal changes in cumulative human impacts on the world's ocean. Nature Communications, 6, 7615.

Hedges, J.I. \& Stern, J.H. (1984) Carbon and nitrogen determinations of carbonatecontaining solids. Limnology and Oceanography, 29, 657-663.

Hicks, N., Bulling, M.T., Solan, M., Raffaelli, D.l., White, P.C.L. \& Paterson, D.M. (2009) Impact of biodiversity-climate futures on primary production and metabolism in a model benthic estuarine system. BMC Ecology, 11, 7.

This article is protected by copyright. All rights reserved. 
Hunter, W.R., Veuger, B. \& Witte, U. (2012) Macrofauna regulate heterotrophic bacterial carbon and nitrogen incorporation in low-oxygen sediments. ISME Journal, 6, 2140-2151.

Hunter, W.R., Jamieson, A., Huvenne, V.A.I. \& Witte, U. (2013) Sediment community responses to marine vs. terrigenous organic matter in a submarine canyon. Biogeosciences, 10, 67-80.

Hunter, W.R., Ogle, N., O'Connor, N.(2018) Biogeochemical responses of intertidal sediments to simulated warming and epi-faunal loss: a mescosm experiment. PANGAEA, https://doi.pangaea.de/10.1594/PANGAEA.892199.

IPCC. (2014) Climate change synthesis report. contribution of working groups I, II and III to the fifth assessment report of the intergovernmental panel on climate change. [Core Writing Team, R.K. Pachauri and L.A. Meyer (eds.)]. IPCC, Geneva, Switzerland, $151 \mathrm{pp}$.

Isbell, F., Gonzalez, A., Loreau, M., Cowles, J., Diaz, S., Hector, A., Mace, G.M., Wardle, D.A., O'Connor, M.I., Duffy, J.E., Turnbull, L.A., Thompson, P.L. \& Larigauderie, A. (2017) Linking the influence and dependence of people on biodiversity across scales. Nature, 546, 65-72.

Jeffreys, R.M., Lavaleye, M.S.S., Bergman, M.J.N., Duineveld, G.C.A. \& Witbaard, R. (2011) Do abyssal scavengers use phytodetritus as a food resource? video and biochemical evidence from the atlantic and mediterranean. Deep Sea Research Part I: Oceanographic Research Papers, 58, 415-428.

Jeffreys, R.M., Wolff, G.A. \& Murty, S.J. (2009) The trophic ecology of key megafaunal species at the pakistan margin: Evidence from stable isotopes and lipid biomarkers. Deep Sea Research Part I: Oceanographic Research Papers, 56, 18161833.

Jones, C.G., Lawton, J.H. \& Shachak, M. (1994) Organisms as ecosystem engineers. Oikos, 69, 373-386.

Jones, D.O.B., Yool, A., Wei, C.L., Henson, S.A., Ruhl, H.A., Watson, R.A. \& Gehlen, M. (2014) Global reductions in seafloor biomass in response to climate change. Global Change Biology, 20, 1861-1872.

Kahlert, M. \& McKie, B.G. (2014) Comparing new and conventional methods to estimate benthic algal biomass and composition in freshwaters. Environmental Science: Processes \& Impacts, 16, 2627-2634.

Kaiser, C., Frank, A., Wild, B., Koranda, M. \& Richter, A. (2010) Negligible contribution from roots to soil-borne phospholipid fatty acid fungal biomarkers 18 :

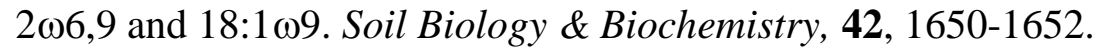

Lopes, R. \& Vidiera, N. (2013) Valuing marine and coastal ecosystem services: An integrated participatory framework. Ocean and Coastal Management, 153e162.

This article is protected by copyright. All rights reserved. 
López-Urrutia, A., San Martin, E., Harris, R.P. \& Irigoien, X. (2009) Scaling the metabolic balance of the oceans. Proceedings of the National Academy of Sciences., 103, 8739-8744.

MacIntyre, H.L., Geider, R.J. \& Miller, D.C. (1996) Microphytobenthos: The ecological role of the "secret garden" of unvegetated, shallow-water marine habitats. I. distribution, abundance and primary production. Estuaries and Coasts, 19, 186-201.

Mayor, D.J., Thornton, B. \& Zuur, A.F. (2012) Resource quantity affects benthic microbial community structure and growth efficiency in a temperate intertidal mudflat. PLoS ONE, 7, e38582.

Mermillod-Blondin, F. \& Rosenberg, R. (2006) Ecosystem engineering: The impact of bioturbation on biogeochemical processes in marine and freshwater benthic habitats. Aquatic Science, 68, 434-442.

Middelburg, J.J., Soetaert, K. \& Herman, P.M.J. (1997) Empirical relationships for use in global diagenetic models. Deep Sea Research Part I: Oceanographic Research Papers, 44, 327-344.

Middelburg, J.J., Barranguet, C., Boschker, H.T.S., Herman, P.M.J., Moens, T. \& Heip, C.H.R. (2000) The fate of intertidal microphytobenthos carbon: An in situ ${ }^{13} \mathrm{C}-$ labeling study. Limnology and Oceanography, 45, 1224-1234.

Miller, D.C., Geider, R.C. \& MacIntyre, H.L. (1996) Microphytobenthos: The ecological role of the "secret garden" of unvegetated, shallow-water marine habitats. II role in sediment stability and shallow water food webs. Estuaries and Coasts, 19, 202-212.

Miyatake, T., Moerdijk-Poortvliet T.C.W., Stal, L.J. \& Boschker, H.T.S. (2014) Tracing carbon flow from microphytobenthos to major bacterial groups in an intertidal marine sediment by using an in situ ${ }^{13} \mathrm{C}$ pulse-chase method. Limnology and Oceanography, 59, 1275-1287.

Morales, M. (2012) Sciplot: Scientific graphing functions for factorial designs. URL https://CRAN.R-project.org/package=sciplot

Morán, X.A.G., Alonso-Sáez, L., Nogueira, E., Ducklow, H.W., González, N., LópezUrrutia, Á, Díaz-Pérez, L., Calvo-Díaz, A., Arandia-Gorostidi, N. \& Huete-Stauffer, T.M. (2015) More, smaller bacteria in response to ocean's warming? Proceedings of the Royal Society B: Biological Sciences, 282.

Mrowicki, R.J. \& O’Connor, N.E. (2015) Wave action modifies the effects of consumer diversity and warming on algal assemblages. ecology. Ecology, 96, 10201029.

O’Connor, N.E. \& Donohue, I. (2013) Environmental context determines multitrophic effects of consumer species loss. Global Change Biology, 19, 431-440.

This article is protected by copyright. All rights reserved. 
O’Connor, N.E., Emmerson, M.C., Crowe, T.P. \& Donohue, I. (2013) Distinguishing between direct and indirect effects of predators in complex ecosystems. Journal of Animal Ecology, 82, 438-448.

Oakes, J.M. \& Eyre, B.D. (2014) Transformation and fate of microphytobenthos carbon in subtropical, intertidal sediments: Potential for long-term carbon retention revealed by ${ }^{13} \mathrm{C}$-labeling. Biogeosciences, 11, 1927-1940.

O'Connor, M.I., Piehler, M.F., Leech, D.M., Anton, A. \& Bruno, J.F. (2009)

Warming and resource availability shift food web structure and metabolism. PLOS Biology, 7, e1000178.

Oviatt, C.A. (1994) Biological considerations in marine enclosure experiments: Challenges and revelations. Oceanography, 7, 45-51.

Pauly, D., Christensen, V., Dalsgaard, J., Froese, R. \& Torres, F. (1998) Fishing down marine food webs. Science, 279, 860-863.

Payne, J.L., Bush, A.M., Heim, N.A., Knope, M.L. \& McCauley, D.J. (2016) Ecological selectivity of the emerging mass extinction in the oceans. Science, 353, 1284-1286.

Piepenburg, D., Blackburn, T.H., von Dorrien, C.F., Gutt, J., Hall, P.O., Hulth, S., Kendall, M.A., Opalinski, K.W., Rachor, E. \& Schmid, M.K. (1995) Partitioning of benthic community respiration in the arctic (northwestern barents sea). Marine Ecology Progress Series, 118, 199-214.

Poloczanska, E.S., Brown, C.J., Sydeman, W.J., Kiessling, W., Schoeman, D.S., Moore, P.J., Brander, K., Bruno, J.F., Buckley, L.B., Burrows, M.T., Duarte, C.M., Halpern, B.S., Holding, J., Kappel, C.V., O/'Connor, M.I., Pandolfi, J.M., Parmesan, C., Schwing, F., Thompson, S.A. \& Richardson, A.J. (2013a) Global imprint of climate change on marine life. Nature Clim Change, 3, 919-925.

Poloczanska, E.S., Brown, C.J., Sydeman, W.J., Kiessling, W., Schoeman, D.S., Moore, P.J., Brander, K., Bruno, J.F., Buckley, L.B., Burrows, M.T., Duarte, C.M., Halpern, B.S., Holding, J., Kappel, C.V., O/'Connor, M.I., Pandolfi, J.M., Parmesan, C., Schwing, F., Thompson, S.A. \& Richardson, A.J. (2013b) Global imprint of climate change on marine life. Nature Clim Change, 3, 919-925.

Queiros, A.A., Birchenough, S.N.R., Bremner, J., Godbold, J.A., Parker, R.E., Romero-Ramirez, A., Reiss, H., Solan, M., Somerfield, P.J., Van Colen, C., Van Hoey, G. \& Widdicombe, S. (2013) A bioturbation classification of european marine infaunal invertebrates. Ecology and Evolution, 3, 1958-1985.

Queiros, A.A., Fernandes, J.A., Faulwetter, S., Nunes, J., Rastrick, S.P.S., Mieszkowska, N., Artioli, Y., Yool, A., Calosi, P., Arvanitidis, C., Findlay, H.S., Barange, M., Cheung, W.W.L. \& Widdicombe, S. (2015) Scaling up experimental ocean acidification and warming research: From individuals to the ecosystem. Global Change Biology, 21, 130-143.

This article is protected by copyright. All rights reserved. 
R Development Core Team. (2009) R: A language and environment for statistical computing. Vienna, Austria. URL http://www.R-project.org/.

Sarmento, H., Montoya, J.M., Vázquez-Domínguez, E., Vaqué, D. \& Gasol, J.M. (2010) Warming effects on marine microbial food web processes: How far can we go when it comes to predictions? Philosophical Transactions of the Royal Society B, $\mathbf{3 6 5}$, 2137-2149.

Spears, B.M., Saunders, J.E., Davidson, I. \& Paterson, D.M. (2008) Microalgal sediment biostabilisation along a salinity gradient in the eden estuary, scotland: Unravelling a paradox. Marine and Freshwater Research, 59, 313-321.

Spivak, A.C., Canuel, E.A., Duffy, J.E. \& Richardson, J.P. (2007) Top-down and bottom-up controls on sediment organic matter composition in an experimental seagrass ecosystem. Limnology and Oceanography, 52, 2595-2607.

Stewart, R.I.A., Dossena, M., Bohan, D.A., Jeppesen, E., Kordas, R.L., Ledger, M.E., Meerhoff, M., Moss, B., Mulder, C., Shurin, J.B., Suttle, B., Thompson, R., Trimmer, M. \& Woodward, G. (2013) Mesocosm experiments as a tool for ecological climatechange research. Advances in Ecological Research, 48, 71-181.

Stoeck, T., Kröncke, I., Duiniveld, G.C.A. \& Palojärvi, A. (2002) Phospholipid fatty acid profiles at depositional and non-depositional sites in the north sea. Marine Ecology Progress Series, 241, 57-70.

Thornton, B., Zhang, Z., Mayes, R.W., Högberg, M.N. \& Midwood, A.J. (2011) Can gas chromatography combustion isotope ratio mass spectrometry be used to quantify organic compound abundance? Rapid Communications in Mass Spectroscopy, 25, 2433-2438.

Tolhurst, T.J., Friend, P.L., Watts, C., Wakefield, R., Black, K.S. \& Paterson, D.M. (2006) The effects of rain on the erosion threshold of intertidal cohesive sediments. Aquatic Ecology, 40, 533-541.

Underwood, A.J. (1997) Experiments in Ecology: Their logical design and interpretation using analysis of variance, $524 \mathrm{pp}$. Cambridge University Press. Cambridge, UK.

Underwood, G.J.C. \& Kronkamp, J. (1999) Primary production by phytoplankton and microphytobenthos in estuaries. Advances in Ecological Research, 29, 93-153.

van Nugteren, P., Herman, P.M.J., Moodley, L., Middelburg, J.J., Vos, M. \& Heip, C.H.R. (2009) Spatial distribution of detrital resources determines the outcome of competition between bacteria and a facultative detritivorous worm. Limnology and Oceanography, 54, 1413-1419.

van Nugteren, P., Moodley, L., Brummer, G.-., Heip, C.H.R., Herman, P.M.J. \& Middelburg, J.J. (2009) Seafloor ecosystem functioning: The importance of organic matter priming. Marine Biology, 156, 2277-2287.

This article is protected by copyright. All rights reserved. 
van Oevelen, D., Soetaert, K., Middelburg, J.J., Herman, P.M.J., Moodley, L., Hamels, I., Moens, T. \& Heip, C.H.R. (2006) Carbon flows through a benthic food web: Integrating biomass, isotope and tracer data. Journal of Marine Research, 64, 453-482.

Weston, N.B. \& Joye, S.B. (2005) Temperature-driven decoupling of key phases of organic matter degradation in marine sediments. Proceedings of the National Academy of Sciences, 102, 17036-17040.

White, D.C., Davis, W.M., Nickels, J.S., King, J.D. \& Bobbie, R.J. (1979)

Determination of the sedimentary microbial biomass by extractable lipid phosphate. Oecologia, 40, 51-62.

Woulds, C., Bouillon, S., Cowie, G.L., Drake, E., Middelburg, J.J. \& Witte, U. (2016) Patterns of carbon processing at the seafloor: The role of faunal and microbial communities in moderating carbon flows. Biogeosciences, 13, 4343-4357.

Woulds, C., Andersson, J.H., Cowie, G.L., Middelburg, J.J. \& Levin, L.A. (2009) The short-term fate of organic carbon in marine sediments: Comparing the pakistan margin to other regions. Deep Sea Research Part II: Topical Studies in Oceanography, 56, 393-402.

Yool, A., Martin, A.P., Anderson, T.R., Bett, B.J., Jones, D.O.B. \& Ruhl, H.A. (2017) Big in the benthos: Future change of seafloor community biomass in a global, body size-resolved model. Global Change Biology, 23, 3554-3566.

Zuur, A.F., Ieno, E.N. \& Elphick, C.S. (2010) A protocol for data exploration to avoid common statistical problems. Methods Ecology and Evolution, 1, 3-14.

This article is protected by copyright. All rights reserved. 


\section{Tables Legends}

Table 1. ANOVA summary tables of the effects of Carcinus presence and temperature upon a) MPB Biomass (Chlorophyll a) and b) the spatial variability of the MPB during each of the four weeks of the experiment. Abbreviations: $T=$ Temperature; $C=$ Carcinus; WB = Water Bath

Table 2. ANOVA summary tables of the effects of Carcinus presence and temperature upon the sediment a) TOC, b) $\mathrm{TO}^{13} \mathrm{C}$, c) PLFA, d) ${ }^{13} \mathrm{C}$-labelled PLFA concentration. Abbreviations: $T=$ Temperature; $C=$ Carcinus; $W B=$ Water Bath .

Table 3. ANOVA summary tables of the effects of Carcinus presence and temperature upon the relative contribution of a) bacterial fatty acids, b) ${ }^{13} \mathrm{C}$-labelled bacterial fatty acids, c) microeukaryote fatty acids PUFAs and d) ${ }^{13} \mathrm{C}$-labelled PUFAs, to the total PLFA and ${ }^{13} \mathrm{C}$-labelled PLFA pools. Abbreviations: $T=$ Temperature; $C=$ Carcinus; $W B=$ Water Bath.

This article is protected by copyright. All rights reserved. 


\section{Figures}

Figure 1. Effects of Carcinus presence and temperature upon the microphytobenthos. Temporal changes in mean ( \pm standard error) a) MPB Biomass (surficial chlorophyll a concentrations) and b) spatial variation in the MPB assemblage between Carcinus present (white ) and absent (grey) treatments, under both ambient ( $8)$ and warming ( $\$$ ) temperature treatments. Inserts show pooled means ( \pm standard error) where significant independent effects of either Carcinus presence (white) / absence (grey) or temperature (labelled) where detected. Significance levels: ${ }^{* *} p<$ $0.001 ;^{* *} p<0.01{ }^{*} p<0.05$. Where significant interactions were identified, groups labeled with the same lowercase letter are not significantly different ( $p>0.05$; Tukey's tests).

Figure 2. Effects of Carcinus presence and temperature upon the sediment geochemistry. Mean ( \pm standard error) concentrations of a) Total Organic Carbon b) ${ }^{13} \mathrm{C}$-labelled Organic Carbon $\left(\mathrm{TO}^{13} \mathrm{C}\right) \mathrm{c}$ ) Total PLFAs and d) ${ }^{13} \mathrm{C}$-labelled PLFAs between Carcinus present (white $\omega^{*}$ ) and absent (grey) treatments, under both ambient ( 8 ) and warming $(\downarrow)$ temperature treatments. Inserts show pooled means $( \pm$ standard error) where significant independent effects of either Carcinus presence (white) / absence (grey) or temperature (labelled) where detected. Significance levels: ${ }^{* * *} p<0.001$; $^{* *} p$ $<0.01{ }^{*} p<0.05$. Where significant interactions were identified, groups labeled with the same lowercase letter are not significantly different ( $p>0.05$; Tukey's tests).

Figure 3. Effects of Carcinus presence and temperature upon the sediment microbial community. Mean ( \pm standard error) contributions of a) bacterial fatty acids b) ${ }^{13} \mathrm{C}$-labelled bacterial Fatty Acids, c) microeukaryote PUFAs and d) ${ }^{13} \mathrm{C}$-labelled microeukaryote PUFAs [relative to the total PLFA or ${ }^{13} \mathrm{C}$-labelled PLFA pools] between Carcinus present (white ) and absent (grey) treatments, under both ambient $(\delta)$ and warming $(\downarrow)$ temperature treatments. Inserts show pooled means $( \pm$ standard error) where significant independent effects of either Carcinus presence (white) / absence (grey) or temperature (labelled) where detected. Significance levels: ${ }^{* * *} p<0.001 ;{ }^{* *} p<$ $0.01 ;^{*} p<0.05$. Where significant interactions were identified, groups labeled with the same lowercase letter are not significantly different ( $p>0.05$; Tukey's tests).

This article is protected by copyright. All rights reserved. 
Table 1.

\begin{tabular}{|c|c|c|c|c|c|c|}
\hline \multicolumn{7}{|c|}{ a) MPB Biomass (Chlorophyll $a$ ) } \\
\hline \multicolumn{7}{|c|}{ Week 0} \\
\hline & df & SS & MS & $\mathbf{F}$ & $p$ & $\eta^{2}$ \\
\hline $\mathrm{T}$ & 1 & 0.199 & 0.199 & 4.526 & 0.050 & - \\
\hline C & 1 & 0.002 & 0.002 & 0.045 & 0.835 & - \\
\hline $\mathrm{T} \times \mathrm{C}$ & 1 & 0.014 & 0.014 & 0.323 & 0.578 & - \\
\hline Resid. & 15 & 0.661 & 0.044 & & & \\
\hline \multicolumn{7}{|l|}{ Error } \\
\hline & df & SS & MS & & & \\
\hline WB & 1 & 0.271 & 0.271 & & & \\
\hline \multicolumn{7}{|c|}{ Week 1} \\
\hline & df & SS & MS & $\mathbf{F}$ & $p$ & $\eta^{2}$ \\
\hline $\mathrm{T}$ & 1 & 0.028 & 0.028 & 0.787 & 0.389 & \\
\hline C & 1 & 0.353 & 0.353 & 9.951 & 0.007 & 0.298 \\
\hline $\mathrm{T} \times \mathrm{C}$ & 1 & 0.001 & 0.001 & 0.004 & 0.948 & \\
\hline Resid. & 15 & 0.532 & 0.036 & & & \\
\hline \multicolumn{7}{|l|}{ Error } \\
\hline & df & SS & MS & & & \\
\hline WB & 1 & 0.271 & 0.271 & & & \\
\hline \multicolumn{7}{|c|}{ Week 2} \\
\hline & df & SS & MS & $\mathbf{F}$ & $p$ & $\eta^{2}$ \\
\hline $\mathrm{T}$ & 1 & 0.019 & 0.019 & 0.268 & 0.612 & - \\
\hline $\mathrm{C}$ & 1 & 0.953 & 0.953 & 13.439 & 0.002 & 0.359 \\
\hline $\mathrm{T} \times \mathrm{C}$ & 1 & 0.124 & 0.124 & 1.741 & 0.207 & - \\
\hline Resid. & 15 & 1.064 & 0.071 & & & \\
\hline \multicolumn{7}{|l|}{ Error } \\
\hline & df & SS & MS & & & \\
\hline WB & 1 & 0.496 & 0.496 & & & \\
\hline \multicolumn{7}{|c|}{ Week 3} \\
\hline & df & SS & MS & $\mathbf{F}$ & $p$ & $\eta^{2}$ \\
\hline $\mathrm{T}$ & 1 & 0.129 & 0.129 & 1.165 & 0.298 & - \\
\hline C & 1 & 0.299 & 0.299 & 2.711 & 0.120 & - \\
\hline T x C & 1 & 0.011 & 0.011 & 0.104 & 0.752 & - \\
\hline Resid. & 15 & 1.656 & 0.110 & & & \\
\hline \multicolumn{7}{|l|}{ Error } \\
\hline & df & SS & MS & & & \\
\hline WB & 1 & 0.016 & 0.0163 & & & \\
\hline
\end{tabular}

This article is protected by copyright. All rights reserved. 


\begin{tabular}{|c|c|c|c|c|c|c|}
\hline \multicolumn{7}{|c|}{ b) MPB Patchiness } \\
\hline \multicolumn{7}{|c|}{ Week 0} \\
\hline & df & SS & MS & $\mathbf{F}$ & $p$ & $\eta^{2}$ \\
\hline $\mathrm{T}$ & 1 & 0.001 & 0.001 & 0.127 & 0.726 & - \\
\hline $\mathrm{C}$ & 1 & 0.003 & 0.003 & 0.347 & 0.565 & - \\
\hline $\mathrm{T} \times \mathrm{C}$ & 1 & 0.005 & 0.005 & 0.521 & 0.482 & - \\
\hline Resid. & 15 & 0.149 & 0.009 & & & \\
\hline \multicolumn{7}{|l|}{ Error } \\
\hline & df & SS & MS & & & \\
\hline WB & 1 & 0.003 & 0.003 & & & \\
\hline \multicolumn{7}{|c|}{ Week 1} \\
\hline & df & SS & MS & $\mathbf{F}$ & $p$ & $\eta^{2}$ \\
\hline $\mathrm{T}$ & 1 & 0.019 & 0.019 & 1.353 & 0.263 & - \\
\hline $\mathrm{C}$ & 1 & 0.255 & 0.255 & 17.997 & $<0.001$ & 0.447 \\
\hline $\mathrm{T} \times \mathrm{C}$ & 1 & 0.064 & 0.064 & 4.524 & 0.049 & 0.112 \\
\hline Resid. & 15 & 0.212 & 0.014 & & & \\
\hline \multicolumn{7}{|l|}{ Error } \\
\hline & df & SS & MS & & & \\
\hline WB & 1 & 0.021 & 0.021 & & & \\
\hline \multicolumn{7}{|c|}{ Week 2} \\
\hline & df & SS & MS & $\mathbf{F}$ & $p$ & $\eta^{2}$ \\
\hline $\mathrm{T}$ & 1 & 0.043 & 0.043 & 1.337 & 0.266 & - \\
\hline $\mathrm{C}$ & 1 & 0.015 & 0.015 & 0.471 & 0.503 & - \\
\hline $\mathrm{T} \times \mathrm{C}$ & 1 & 0.001 & 0.001 & 0.037 & 0.851 & - \\
\hline Resid. & 15 & 0.485 & 0.032 & & & \\
\hline \multicolumn{7}{|l|}{ Error } \\
\hline & df & SS & MS & & & \\
\hline WB & 1 & 0.024 & 0.024 & & & \\
\hline \multicolumn{7}{|c|}{ Week 3} \\
\hline & df & SS & MS & $\mathbf{F}$ & $p$ & $\eta^{2}$ \\
\hline $\mathrm{T}$ & 1 & 0.003 & 0.003 & 0.090 & 0.768 & - \\
\hline $\mathrm{C}$ & 1 & 0.008 & 0.008 & 0.273 & 0.609 & - \\
\hline $\mathrm{T} \times \mathrm{C}$ & 1 & 0.104 & 0.104 & 3.728 & 0.073 & - \\
\hline Resid. & 15 & 0.420 & 0.028 & & & \\
\hline \multicolumn{7}{|l|}{ Error } \\
\hline & df & SS & MS & & & \\
\hline WB & 1 & 0.001 & 0.001 & & & \\
\hline
\end{tabular}

This article is protected by copyright. All rights reserved. 
Table 2.

\begin{tabular}{|c|c|c|c|c|c|c|}
\hline \multicolumn{7}{|c|}{ a) Sediment TOC concentrations } \\
\hline & df & SS & MS & $\mathbf{F}$ & $p$ & $\eta^{2}$ \\
\hline $\mathrm{T}$ & 1 & 11.140 & 11.145 & 53.585 & 0.078 & \\
\hline $\mathrm{C}$ & 1 & 15.330 & 15.328 & $\begin{array}{ll}8 & 4.930\end{array}$ & 0.042 & 0.198 \\
\hline Tx C & 1 & 0.020 & 0.021 & $\begin{array}{ll}1 & 0.007\end{array}$ & 0.935 & - \\
\hline Resid. & 15 & 46.630 & & 3.109 & & \\
\hline \multicolumn{7}{|l|}{ Error } \\
\hline & df & SS & MS & & & \\
\hline WB & 1 & 4.144 & 4.144 & & & \\
\hline \multicolumn{7}{|c|}{ b) Sediment $\mathrm{TO}^{13} \mathrm{C}$ concentrations } \\
\hline & df & SS & MS & $\mathbf{F}$ & $p$ & $\eta^{2}$ \\
\hline $\mathrm{T}$ & 1 & 2105 & 2105 & 5.107 & 0.039 & 0.149 \\
\hline $\mathrm{C}$ & 1 & 103 & 103 & 0.249 & 0.625 & - \\
\hline $\mathrm{T} \times \mathrm{C}$ & 1 & 4939 & 4939 & 11.984 & 4 0.003 & 0.352 \\
\hline Resid. & 15 & 6183 & 412 & & & \\
\hline \multicolumn{7}{|l|}{ Error } \\
\hline & df & SS & MS & & & \\
\hline WB & 1 & 706 & 706 & & & \\
\hline \multicolumn{7}{|c|}{ c) Total PLFAs } \\
\hline & df & SS & MS & $\mathbf{F}$ & $p$ & $\eta^{2}$ \\
\hline $\mathrm{T}$ & 1 & 0.296 & 0.297 & 2.806 & 0.115 & \\
\hline $\mathrm{C}$ & 1 & 0.006 & 0.006 & 0.053 & 0.822 & - \\
\hline $\mathrm{T} \times \mathrm{C}$ & 1 & 0.166 & 0.166 & 1.573 & 0.229 & - \\
\hline Resid. & 15 & 1.581 & 0.105 & & & \\
\hline \multicolumn{7}{|l|}{ Error } \\
\hline & df & SS & MS & & & \\
\hline WB & 1 & 0.362 & 0.362 & & & \\
\hline \multicolumn{7}{|c|}{ d) ${ }^{13}$ C-labelled PLFAs } \\
\hline & df & SS & MS & $\mathbf{F}$ & $p$ & $\eta^{2}$ \\
\hline $\mathrm{T}$ & 1 & 45950 & 45950 & 20.887 & $<0.001$ & 0.472 \\
\hline $\mathrm{C}$ & 1 & 1776 & 1776 & 0.807 & 0.383 & - \\
\hline $\mathrm{T} \times \mathrm{C}$ & 1 & 6187 & 6187 & 2.812 & 0.114 & - \\
\hline Resid. & 15 & 33000 & 2200 & & & \\
\hline \multicolumn{7}{|l|}{ Error } \\
\hline & df & SS & MS & & & \\
\hline WB & 1 & 10530 & 10530 & & & \\
\hline
\end{tabular}

This article is protected by copyright. All rights reserved. 
Table 3.

\begin{tabular}{|c|c|c|c|c|c|c|}
\hline \multicolumn{7}{|c|}{ a) Bacterial FAs } \\
\hline & df & SS & MS & $\mathbf{F}$ & $p$ & $\eta^{2}$ \\
\hline $\mathrm{T}$ & 1 & 25.96 & 25.956 & 10.942 & 0.005 & 0.301 \\
\hline C & 1 & 1.56 & 1.565 & 0.660 & 0.429 & - \\
\hline $\mathrm{T} \times \mathrm{C}$ & 1 & 6.61 & 6.609 & 2.786 & 0.115 & - \\
\hline Resid. & 15 & 35.58 & 2.372 & & & \\
\hline \multicolumn{7}{|l|}{ Error } \\
\hline & df & SS & MS & & & \\
\hline $\mathrm{T}$ & 1 & 16.46 & 16.46 & & & \\
\hline \multicolumn{7}{|c|}{ b) ${ }^{13}$ C-labelled Bacterial FAs } \\
\hline & df & SS & MS & $\mathbf{F}$ & $p$ & $\eta^{2}$ \\
\hline $\mathrm{T}$ & 1 & 315.5 & 315.52 & 7.888 & 0.013 & 0.249 \\
\hline $\mathrm{C}$ & 1 & 17.5 & 17.49 & 0.437 & 0.519 & - \\
\hline $\mathrm{T} \times \mathrm{C}$ & 1 & 244.8 & 244.77 & 6.120 & 0.026 & 0.194 \\
\hline Resid. & 15 & 600.0 & 40.00 & & & \\
\hline
\end{tabular}

Error

\begin{tabular}{|c|c|c|c|c|c|}
\hline $\mathrm{T}$ & $\begin{array}{c}\text { df } \\
1\end{array}$ & $\begin{array}{l}\text { SS } \\
86.2\end{array}$ & $\begin{array}{l}\text { MS } \\
86.2\end{array}$ & & \\
\hline \multicolumn{6}{|c|}{ c) PUFAs } \\
\hline & df & SS & MS & $\mathbf{F}$ & $\eta^{2}$ \\
\hline $\mathrm{T}$ & 1 & 0.609 & 0.609 & $40.77<\mathbf{0 . 0 0 1}$ & 0.117 \\
\hline $\mathrm{C}$ & 1 & 2.421 & 2.421 & $162.02<\mathbf{0 . 0 0 1}$ & 0.463 \\
\hline $\mathrm{T} \times \mathrm{C}$ & 1 & 1.644 & 1.644 & $110.02<\mathbf{0 . 0 0 1}$ & 0.315 \\
\hline Resid. & 15 & 0.224 & 0.015 & & \\
\hline
\end{tabular}

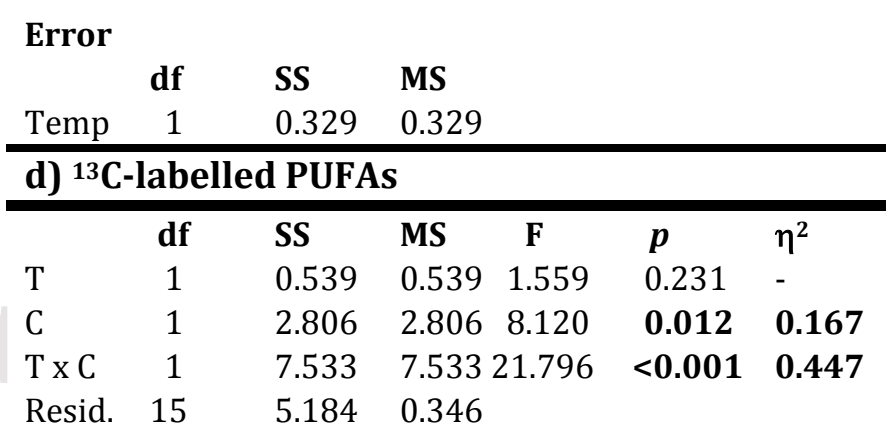

\begin{tabular}{lrll} 
Error & & & \\
& Df & SS & MS \\
$\mathrm{T}$ & 1 & 0.779 & 0.779 \\
\hline
\end{tabular}

This article is protected by copyright. All rights reserved. 

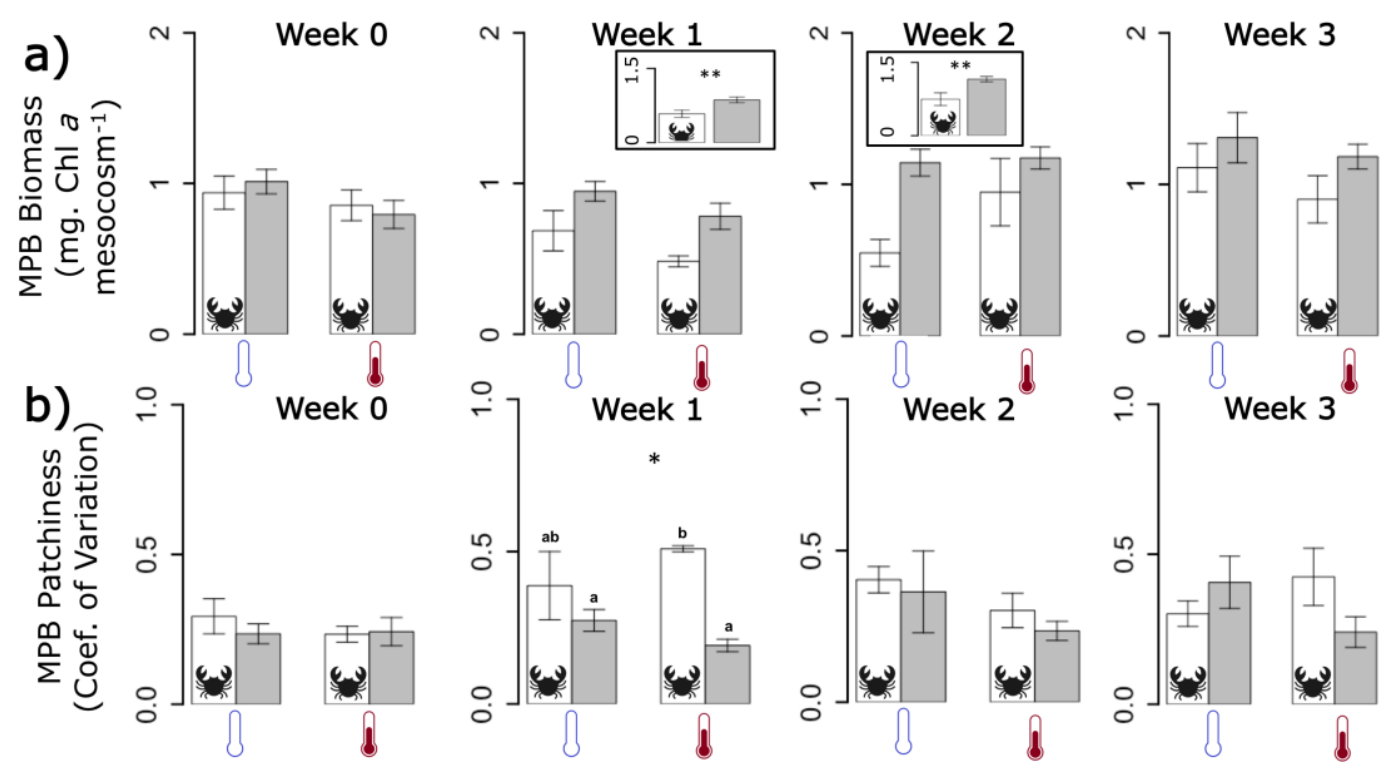

This article is protected by copyright. All rights reserved. 

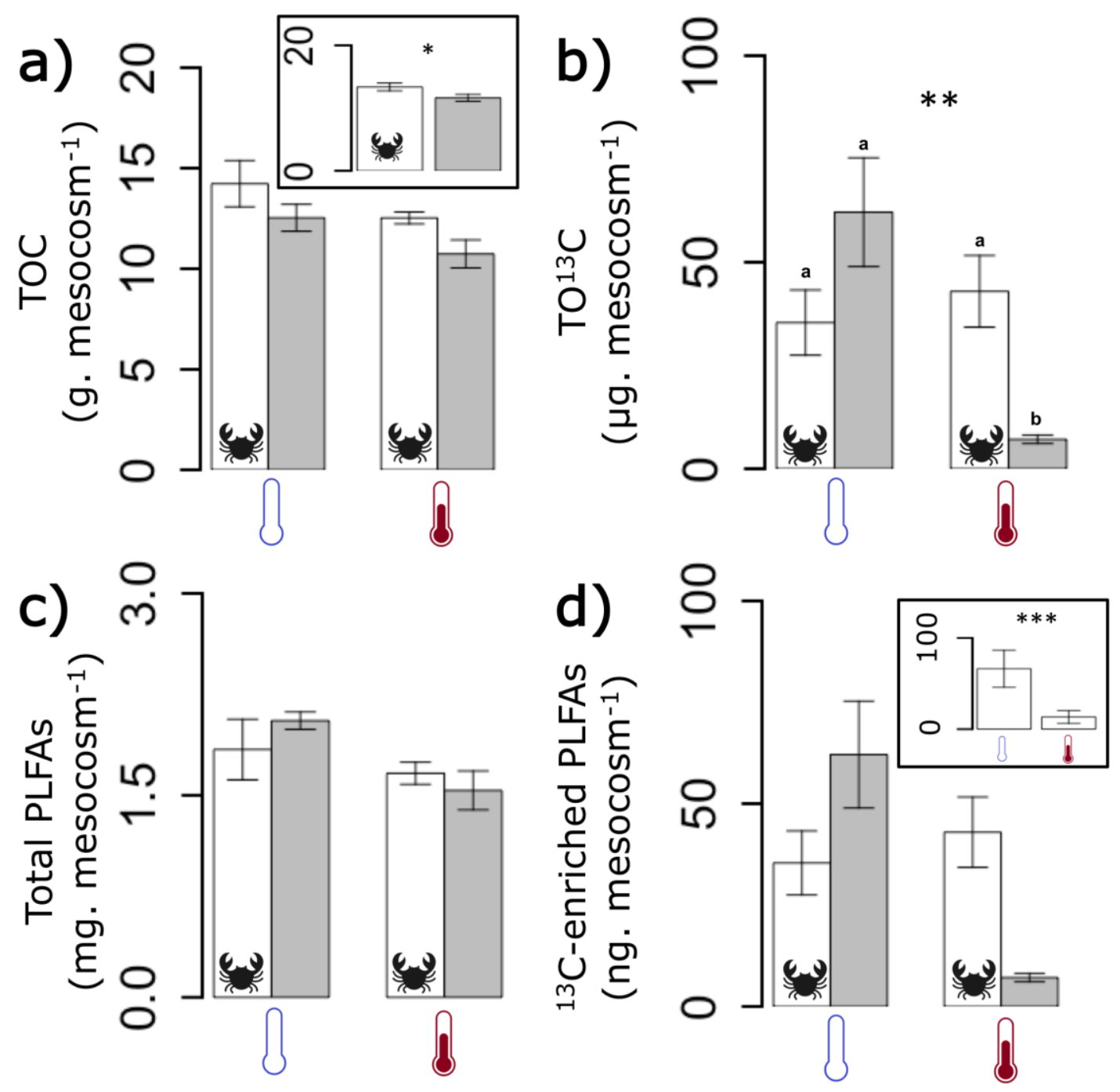

This article is protected by copyright. All rights reserved. 

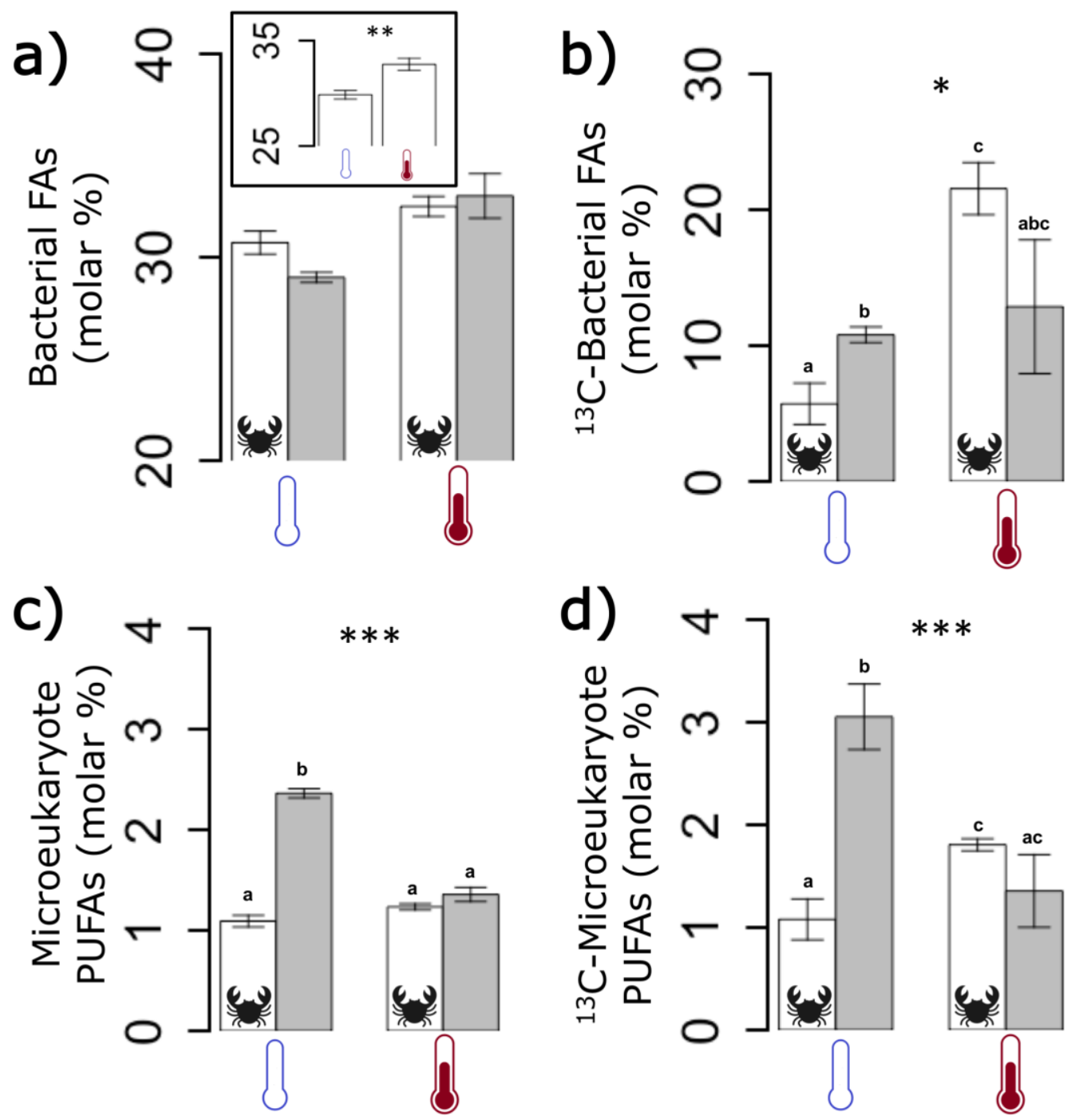

This article is protected by copyright. All rights reserved. 